\title{
DÜBLIN
}

Technological University Dublin

ARROW@TU Dublin

\section{Extending and Measuring the Quality of Fresh-cut Fruit and Vegetables: a Review}

\author{
Catherine Barry-Ryan \\ Technological University Dublin, Catherine.Barryryan@tudublin.ie \\ Ana Belen Martin-Diana \\ Technological University Dublin, anabelen.martindiana@tudublin.ie \\ Daniel Rico \\ Technological University Dublin, daniel.rico@tudublin.ie
}

See next page for additional authors

Follow this and additional works at: https://arrow.tudublin.ie/schfsehart

Part of the Other Food Science Commons

\section{Recommended Citation}

Barry-Ryan,C. et al. (2007) Extending and measuring the quality of fresh-cut fruit and vegetables: a review. Trends in Food Science \& Technology, 18 (2007) 373-386. doi:10.1016/j.tifs.2007.03.011

This Article is brought to you for free and open access by the School of Food Science and Environmental Health at ARROW@TU Dublin. It has been accepted for inclusion in Articles by an authorized administrator of ARROW@TU Dublin. For more information, please contact arrow.admin@tudublin.ie, aisling.coyne@tudublin.ie, gerard.connolly@tudublin.ie.

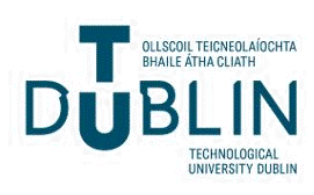


Authors

Catherine Barry-Ryan, Ana Belen Martin-Diana, Daniel Rico, and J. Barat

This article is available at ARROW@TU Dublin: https://arrow.tudublin.ie/schfsehart/24 


\section{Extending and measuring the quality of fresh-cut fruit and vegetables: a review}

Trends in Food Science \& Technology 18 (2007) 373-386

\section{Ricoa, A.B. Martın-Dianaa, J.M. Baratb and C. Barry-Ryana}

a. School of Food Science and Environmental Health, Dublin Institute of Technology (DIT), Cathal Brugha Street, Dublin 1, Ireland b. Institute of Food Engineering for Development, Polytechnic University of Valencia, Camino de Vera s/n, 46022, Valencia, Spain

The market sales of ready-to-use fresh vegetables have grown rapidly in recent decades as a result of changes in consumer attitudes, especially consumption of fresh-cut lettuce and carrot due to their use in prepared salads. Chlorine solutions have been widely used to sanitise fruit and vegetables in the freshcut industry. However, the association of chlorine with the possible formation of carcinogenic chlorinated compounds in water has called into question the use of chlorine in food processing. There is a real need to find alternatives for preservation of freshcut fruit and vegetables in order to improve the efficacy of washing treatments. Alternatives or modified methods have been proposed, as antioxidants, irradiation, ozone, organics acids, modified atmosphere packaging, whey permeate, etc.; however, none have yet gained widespread acceptance by the industry. For this reason the development of alternatives and markers in order to measure the efficacy of these alternatives are needed.

Introduction

Tremendous growth in the ready-to-use (RTU) vegetable industry (w10\% p.a.) has been largely due to increasing demand for fresh, healthy and convenient foods. A substantial portion of vitamins and minerals in the diet comes from fruit and vegetable consumption (Klein, 1987). There is mounting evidence to support the alleviation of many degenerative diseases including cardiovascular disease, cancer and ageing by the consumption of fruit and vegetables (Kaur \& Kapoor, 2001). These beneficial health effects of fruit and vegetables have been attributed to the presence of antioxidants that act as receptors of free radicals. Ascorbic acid and b-carotene are the antioxidants present in the greatest quantities in fruit and vegetables.

Consumers have also become more critical of the use of synthetic additives to preserve food or enhance characteristics such as colour and flavour (Bruhn, 2000). Ohlsson (2002) suggests that minimal processing techniques have emerged to meet the challenge of replacing traditional methods of preservation while retaining nutritional and sensory quality. RTU vegetables typically involve peeling, slicing, dicing or shredding prior to packaging and storage (Barry-Ryan \& O'Beirne, 1999). The International Fresh-cut Produce Association (IFPA) defines fresh-cut products as fruit or vegetables that have been trimmed and/or peeled and/or cut into $100 \%$ usable product that is bagged or pre-packaged to offer consumers high nutrition, convenience, and flavour while still maintaining its freshness (Lamikanra, 2002).

It is well-known that processing of vegetables promotes a faster physiological deterioration, biochemical changes and microbial degradation of the product even when only slight processing operations can be used (O'Beirne \& Francis, 2003), which may result in degradation of the colour, texture and flavour (Kabir, 1994; Varoquaux \& Wiley, 1994). While conventional food-processing methods extend the shelf-life of fruit and vegetables, the minimal processing to which fresh-cut fruit and vegetables are subjected renders products highly perishable, requiring chilled storage to ensure a reasonable shelf-life (Garcia \& Barret, 2002).

Microorganisms are natural contaminants of fresh produce and minimally processed fresh-cut products, and contamination arises from a number of sources, including postharvest handling and processing (Beuchat, 1996). Due to the nature of the treatments applied to this type of product, a favourable environment and time for proliferation of spoilage organisms and microorganisms of public health significance is created (Ahvenainen, 1996; Francis, Thomas, \& O'Beirne, 1999). 
The vast majority of fresh minimally processed produce manufacturers use chlorine-based washing and decontamination procedures (Seymour, 1999). There is a controversy about the formation of carcinogenic chlorinated compounds in water (chloramines and trihalomethanes), calling into question the use of chlorine (Wei et al., 1999). The current concern associated with chlorine outlines the need for research on other treatments suitable for use on fresh-cut products. New techniques for maintaining quality while inhibiting undesired microbial growth are demanded in all the steps of the production and distribution chain, as microorganisms adapt to survive in the presence of previously effective control methods (Allende \& Artes, 2003a, 2003b).

Although this work is focused in minimally processed fruit and vegetables, especially attention has been done in fresh-cut lettuce and carrots. They are the most popular ready-to-eat vegetables, and they provided information about two different models of vegetable (leafy and root).

Evaluating the quality of minimally

processed vegetables

Quality of fresh-cut fruit and vegetable products determines the value to the consumer and is a combination of parameters including appearance, texture, flavour, and nutritional value (Kader, 2002). The relative importance of each quality parameter depends upon the commodity or the product and whether it is eaten fresh (with or without flavour modifiers, such as dressings and dips) or cooked. Consumers judge quality of fresh-cut fruit and vegetables on the basis of appearance and freshness at the time of purchase. However, subsequent purchases depend upon the consumer's satisfaction in terms of texture and flavour of the product. Consumers are also interested in the nutritional quality and safety of fresh-cut products.

Everyone uses a different set of criteria to interpret the quality of a product. The term acceptability is a practical approach to quality by comparing it to a criterion, the quality limit. Below that limit the product is rejected (Tijskens, 2000). The acceptance limit is primarily defined by economic and psychological factors; the quality of a product is largely defined by its intrinsic properties. For fruit and vegetables it is product properties such as colour, firmness and taste change over time. Shelf-life is the time before the product attributes drops below the acceptance limit under standardised storage conditions (Tijskens, 2000).

Techniques to extend the quality of minimally processed fruit and vegetables

Every step the produce undergoes, from cultivation to the shelf, is important from the point of view of quality and safety. Guidelines for packing fresh or minimally processed fruit and vegetables generally specify a washing or sanitising step to remove dirt, pesticide residues, and microorganisms responsible for quality loss and decay (Sapers, 2003). Wounding and other minimal processing procedures can cause physiological effects, including ethylene production, increase in respiration, membrane deterioration, water loss, susceptibility to microbiological spoilage, loss of chlorophyll, formation of pigments, loss of acidity, increase in sweetness, formation of flavour volatiles, tissue softening, enzymatic browning, lipolysis and lipid oxidation (Toivonen \& De-Ell, 2002). The current published data suggest that none of the available washing and sanitising methods, including some of the newest sanitising agents such as chlorine dioxide and ozone, can guarantee the microbiological quality of minimally processed vegetables without compromising their sensorial quality (Beuchat, Nail, Adler, \& Clavero, 1998; Brackett, 1999; Ongeng, Devlieghere, Debevere, Coosemans, \& Ryckeboer, 2006; Sapers, 2003).

Colour evaluation of minimally processed vegetables

Consumers take product appearance into consideration as a primary criterion (Kays, 1999); colour has been considered to have a key role in food choice, food preference and acceptability, and may even influence taste thresholds, sweetness perception and pleasantness (Clydesdale, 1993). Colour is one of the main attributes, along with texture, that characterises the freshness of most vegetables. Lettuce and carrot can undergo changes in colour due to different biochemical processes, mainly chlorophyll degradation and browning appearance in the case of the lettuce, and carotene degradation, whiteness and browning in the case of the carrot (Bolin \& Huxoll, 1991a; CisnerosZevallos, Saltveit, \& Krochta, 1997; Ihl, Aravena, Scheuermann, Uquiche, \& Bifani, 2003).

Browning of fresh fruit and vegetables reduces quality (Shewfelt, 1994) and is often the factor limiting shelf-life and marketability of fresh-cut lettuce (Bolin \& Huxsoll, 1991b; Couture, Cantwell, Ke, \& Saltveit, 1993; LopezGalvez, Saltveit, \& Cantwell, 1996). Comparing wounded fruit and vegetables, there is a lag time for the apparition of browning in the case of vegetables. This can be explained due to the de novo biosynthesis of polyphenols (Murata, Tanaka, Minoura, \& Homma, 2004). Apples contain a sufficient amount of polyphenols that cause rapid enzymatic browning, while lettuce contains a far lower amount of these compounds (Murata, Noda, \& Homma, 1995).

Lettuce presents two types of browning, edge browning and russet spotting (Lopez-Galvez et al., 1996). Wounding (e.g., cutting, cracking or breaking) of lettuce produces a signal that migrates through the tissue and induces the synthesis of enzymes in the metabolic pathway responsible for increased production of phenolic compounds and browning (Ke \& Saltveit, 1989). Research for controlling lettuce browning has been focused on the control of phenylalanine ammonialyase (PAL) activity, which is the ratelimiting enzyme of the phenylpropanoid pathway and is generally induced by wounding (Hahlbrock \& Scheel, 1989; Hisaminato, Murata, \& Homma, 2001; LoaizaVelarde, Tomas-Barberan, \& Saltveit, 1997; Saltveit, 2000). But other enzymes are involved as well in the 
enzymatic browning. The origin of the brown pigment is complex and not fully understood, but is known to involve the oxidation of polyphenols by peroxidase (POD) and polyphenol oxidase (PPO) enzymes (Ke \& Saltveit, 1989; Nicoli, Elizalbe, Piotti, \& Lerici, 1991; Zawistowski, Biliaderis, \& Eskin, 1995).

Carrots challenged by environmental and postharvest stress factors can synthesize phenolic compounds along with wound barriers such as lignin (Babic, Amiot, Nguyen-the, \& Aubert, 1993; Howard, Griffin, \& Lee, 1994; Talcott \& Howard, 1999). In fact, the major role of these compounds is the defence of plant tissue from microbial and oxidative damage. Lignin formation increases whiteness of carrot samples and the activation of certain enzymes after the processing can lead to degradation of antioxidants, as occurs with the lipoxygenase and carotenes (Howard \& Dewi, 1996; Howard \& Griffin, 1993). Correlation between whitening and the activity of enzymes such as peroxidase has also been found (Howard et al., 1994).

Another factor that leads to a discolouration of carrot samples, increasing the whiteness, is the reversible surface dehydration of the outer layers (Cisneros-Zevallos et al., 1997). When analysing the colour using a colorimeter, increases in luminosity can be correlated with the development of whiteness in the samples, as well as a decrease of luminosity can be an indication of browning appearance.

Texture evaluation of minimally processed vegetables

Minimally processed vegetables that maintain firm, crunchy texture are highly desirable because consumers associate these textures with freshness and wholesomeness (Bourne, 2002; Fillion \& Kilcast, 2002; Szczesniak, 1998). Indeed, the appearance of a soft or limp product may give rise to consumer rejection prior to consumption. Textural changes in vegetables are related to certain enzymatic and non-enzymatic processes. Enzymatic degradation of pectins is catalysed by pectin methylesterase (PME) and polygalacturonase (PG) (Van Buren, 1979). Pectin is first partially demethylated by PME, and later depolymerised by PG to polygalacturonic acid causing a loss of firmness (Vu et al., 2004). However, the controlled activation of PME results in improvement of the texture, as it increases the cross-linking between pectin chains and cations (Roy, Taylor, \& Kramer, 2001). This effect is favoured in the case of carrots as endogenous PG activity is almost nonexistent (Stratilova et al., 1998). The stimulation of PME activity with mild heating treatments has been correlated with texture maintenance (Chang, Liao, \& Wu, 1996; Ni, Lin, \& Barrett, 2005; Van Buren, 1979).

Iceberg lettuce is very popular probably due to its crispness and attractive yellow-green colour. However, after cutting, the product undergoes different undesirable biochemical reactions associated with wounding (Brecht, 1995; Watada \& Qi, 1999). Texture is seldom maintained for more than 10 days, even under optimal storage conditions. The texture evaluation of the lettuce is relatively difficult due to its heterogeneity. Photosynthetic and vascular tissues present vastly different textural properties (Toole, Parker, Smith, \& Waldron, 2000). Some studies have shown certain sensitivity and repeatability using the Kramer cell to evaluate texture in lettuce (Baur, Klaiber, Wei, Hammes, \& Carle, 2005; Han, Gomes-Feitosa, Castell-Perez, Moreira, \& Silva, 2004). In these studies the texture is evaluated using the maximum load to break the sample. But an important problem is the difficulty of how to evaluate the crispness characteristic using the readings obtained from the texture tests (Harker, Stec, Hallett, \& Bennett, 1997; Vickers, 1988). In the case of the carrot, it can be easier to evaluate textural characteristics, mainly firmness, due to the consistency of the samples. Structural analysis, e.g. Cryo-SEM micrographs (Rico et al., 2006), is another method to assess texture of the samples (Aguilera, 2005).

Respiration of minimally processed vegetables

Minimally processed vegetables are living tissues even after treatment. Damaged plant tissues exhibit an increase in respiratory rate (Laties, 1978). Practical experience has demonstrated that tissues with high respiratory rates and/ or low energy reserves have shorter postharvest lives (Eskin, 1990). Modifying the atmosphere composition in which the produce is stored is usually done to slow down the respiration rate, to reduce product metabolism and maturation (Kader, Zagory, \& Kerbel, 1989), losses in fresh weight and in dry matter (Bottcher, Ghunter, \& Kabelitz, 2003). Treatments applied after or before the wounding can affect also the respiration rate (Del Nobile, Baiano, Benedetto, \& Massignan, 2006; Lewicki, Gondek, Wtrowa-Raichert, \& Nowak, 2001). A practical approach to evaluate the respiration rate when comparing similar samples can be carried out by monitoring the composition of the headspace in the packages (Del Nobile et al., 2006; Klaiber, Baur, Wolf, Hammes, \& Carle, 2005). The concentration of oxygen and carbon dioxide inside the headspaces is related to the metabolic state of the samples.

The levels of oxygen can have other effects on quality, e.g. inactivating enzymatic reactions. Because PPO requires $\mathrm{O}_{2}$ to induce cut surface discolouration, reducing the amount of $\mathrm{O}_{2}$ in the package of fresh-cut product by vacuum, MAP or gas flushing may reduce cut surface discolouration, although not completely stop it.

$\mathrm{pH}$ of minimally processed vegetables

Minimally processed vegetables belong to the low-acid foods ( $\mathrm{pH}$ 5.8e6.0) (Willkox, Mercier, Hendrickx, \& Tobback, 1993). Processing and storage conditions can affect the $\mathrm{pH}$ of the samples, e.g. high levels of $\mathrm{CO}_{2}(\mathrm{Ke}$, Mateos, Siriphanich, Li, \& Kader, 1993). The $\mathrm{pH}$ of the vegetables studied is considered to be adequate in a range of $5 \mathrm{e} 6.5$ for quality retention (Adams, 1991; Beuchat, 1992). In the case of fresh-cut Iceberg lettuce, the pH during storage is maintained or slightly decreased (Bolin \& 
Huxsoll, 1991b). A factor linking $\mathrm{pH}$ and a main quality marker, browning, is the activity of PPO. PPO most effectively catalyses cut surface discolouration at a neutral $\mathrm{pH}$ of approximately 7 .

\section{Microbiology of minimally processed vegetables}

The natural microflora of fresh-cut vegetables includes bacteria, yeast and moulds. The natural microbial load depend to a great extend on the type of vegetable, environment considerations, seasonality and the conditions under which a particular vegetable is grown (Francis et al., 1999). The main characteristics of minimally processed vegetables increasing the probabilities of microbial spoilage and contamination include (1) the presence of cut surfaces and increased moisture content, (2) as minimally processed, sterility or microbial stability of these product can not be ensured, (3) the active metabolism of plant tissue and finally (4) the confinement of the product in a modified atmosphere package (Nguyen-the \& Carlin, 1994).

Large differences in microbial counts have been reported between batches of vegetable products. This has been attributed to numerous factors such as ambient conditions during harvest, the presence of soil accompanying the product, postharvest handling procedure, and the natural variability of the product (Ponce, Roura, Del Valle, \& Fritz, 2002). Microorganisms impact the economic value of freshcut products by decreasing product shelf-life, through spoilage, and by posing a risk to public health by causing foodborne disease (Nguyen-the \& Carlin, 1994).

\section{Sensory evaluation of minimally processed vegetables}

The quality of a fresh produce encompasses sensory, nutritional and functional properties among others. Freshcut products minimally processed appeal to the consumer as if they were non-processed. Many studies try to correlate objective measurements of parameters as colour and texture, obtained from different apparatus as texturometers colorimeters, image analysis software or gas chromatographs among others, with results obtained from sensory evaluation. Other quality parameters as taste and flavour are much more difficult to evaluate objectively. The consumer integrates all sensory inputs e appearance, texture off-flavours and odours e into a final judgement of the acceptability of that fruit or vegetable.

In order to get an appropriate implementation of alternative treatments, sensory evaluations need to be done to ensure the perceived quality of a determined product is not negatively affected. An essential help in the determination of shelf-life is the descriptive analysis, the most sophisticated methodology available for these types of studies, since this test provides complete sensory description in basis of the quality and differences with standards methods (Luna-Guzman, Cantwell, \& Barrett, 1999; Martin-Diana et al., 2005a, 2005b). Difference test is also used to find changes in the perception of the consumer with respect to fresh-cut produce (Saftner, Baj, Abbott, \& Lee, 2003).
Nutritional content of minimally processed vegetables

The fresh-cut industry claims their products are convenient and healthy alternatives to fulfill the dietary needs for fresh food and many fast food companies are diversifying their menu in order to offer a range of ready-to-eat salads to their clients. However, the many changes that happen in fruit and vegetables during harvesting, handling and processing can affect antioxidant status (Lindley, 1998). Klein (1987) reviewed the nutritional consequences of minimal processing on fruit and vegetables and concluded that conditions able to maintain desirable sensory characteristics will also preserve nutrients. Decrease in the antioxidant activity after processing was reported for fresh-cut spinach (Gil, Ferreres, \& Tomas-Barberan, 1999) and fresh-cut mandarin (Piga, Agabbio, Gambella, \& Nicoli, 2002). Otherwise, wounding caused an increase in antioxidant activity of Iceberg and Romaine lettuce (Kang \& Saltveit, 2002). Levels of ascorbic acid, carotenoids or polyphenols can reflect the variations in antioxidant capacity of fruit and vegetables (Klein, 1987; Lana \& Tijskens, 2006).

\section{Chemical-based washing treatments for minimally processed fruit and vegetables Chlorine}

Chlorine-based chemicals, particularly liquid chlorine and hypochlorite, are probably the most widely used sanitisers for decontaminating fresh produce. Chlorine compounds are usually used at levels of $50 \mathrm{e} 200 \mathrm{ppm}$ free chlorine and with typical contact times of less than 5 min (Francis \& O'Beirne, 2002; Watada \& Qi, 1999). Although chlorine is more effective in solution at acidic $\mathrm{pH}$ levels, in order to minimise the corrosion of processing equipment, chlorine-based sanitisers are usually used at $\mathrm{pH}$ values between 6.0 and 7.5 (Beuchat, 2000). Washing with chlorinated water has been traditionally applied to decontaminate vegetables, but several reports have questioned its efficacy (Adams et al., 1989; Beuchat, 1999; Li, Brackett, Chen, \& Beuchat, 2001; Nguyen-the \& Carlin, 1994; Zhang \& Farber, 1996). Future regulatory restrictions on the use of chlorine are likely and will require the development of functional alternatives. In some European countries including Germany, The Netherlands, Switzerland and Belgium the use of chlorine in RTU products is prohibited (Carlin \& Nguyen-the, 1999). As a consequence, several innovative approaches have been explored for the decontamination of minimally processed vegetables. The bulk of them have been devoted to eliminate pathogens (Beuchat, 2000; Parish et al., 2003), and little research has appeared on spoilage microorganisms and the effect of these methods on the sensory attributes of the minimally processed vegetables and their nutritional value and shelf-life (Allende \& Artes, 2003a, 2003b; Li, Brackett, Shewfelt, \& Beuchat, 2001).

Chlorine dioxide

Chlorine dioxide $\left(\mathrm{ClO}_{2}\right)$ has a high oxidation capacity, of about 2.5 times greater than chlorine (Benarde, Israel, 
Oliveri, \& Granstrom, 1965). In addition, it does not react with nitrogen-containing compounds or ammonia to form dangerous chloramines compounds (White, 1992). It is accepted for use in washing fruits and vegetables (FDA, 1998) and many studies have demonstrated its antimicrobial activity (Han, Guentert, Smith, Linton, \& Nelson, 1999; Han, Sherman, Linton, Nielsen, \& Nelson, 2000). Singh, Singh, Bhunia, and Stroshine (2002) treated Escherichia coli O157:H7-inoculated baby carrot and fresh-cut lettuce with chlorine dioxide. Others studies have showed the efficacy of $\mathrm{ClO}_{2}$ in the inactivation of Listeria monocytogenes and Salmonella Typhimurium (Lee, Costello, \& Kang, 2004). These authors found the effective treatment, combining chlorine dioxide, ozone and thyme essential oil, may affect product organoleptical properties.

\section{Organic acids}

Organic acids (e.g. lactic acid, citric acid, acetic acid, tartaric acid) have been described as strong antimicrobial agents against psychrophilic and mesophilic microorganisms in fresh-cut fruit and vegetables (Bari et al., 2005; Uyttendaele, Neyts, Vanderswalmen, Notebaert, \& Debevere, 2004). The antimicrobial action of organic acids is due to $\mathrm{pH}$ reduction in the environment, disruption of membrane transport and/or permeability, anion accumulation, or a reduction in internal cellular $\mathrm{pH}$ by the dissociation of hydrogen ions from the acid (Beuchat, 2000). Citric acid and ascorbic acid were used to reduce microbial populations on salad vegetables (Priepke, Wei, \& Nelso, 1976; Shapiro $\&$ Holder, 1960). Ascorbic acid (L-ascorbic acid) and its various neutral salts and other derivatives have been the leading Generally Recognised as Safe (GRAS) antioxidants for use on fruit and vegetables and in fruit juices, for the prevention of browning and other oxidative reactions (Bauernfeind \& Pinkert, 1970). Ascorbic acid also acts as an oxygen scavenger, removing molecular oxygen in polyphenol oxidase reactions. Polyphenol oxidase inhibition by ascorbic acid has been attributed to the reduction of enzymatically formed o-quinones to their precursor diphenols (Fig. 1).

\section{Hydrogen peroxide}

Hydrogen peroxide possesses bactericidal and inhibitory activity due to its properties as an oxidant, and due to its capacity to generate other cytotoxic oxidising species such as hydroxyl radicals (Juven \& Pierson, 1996). The sporicidal activity of $\mathrm{H}_{2} \mathrm{O}_{2}$ coupled with rapid breakdown makes it a desirable sterilising agent for use on some food contact surfaces and packaging materials in aseptic filling operations. Residual $\mathrm{H}_{2} \mathrm{O}_{2}$ levels may vary depending on the presence or absence of peroxidase in the produce item (Parish et al., 2003). Treatment by dipping in $\mathrm{H}_{2} \mathrm{O}_{2}$ solution reduced microbial populations on fresh-cut bell peppers, cucumber, zucchini, cantaloupe, and honeydew melon, but did not alter sensory characteristics (Beuchat \& Ryu, 1997; Park \& Beuchat, 1999). Shredded lettuce was severely browned upon dipping in a solution of $\mathrm{H}_{2} \mathrm{O}_{2}$ (Parish et al., 2003).

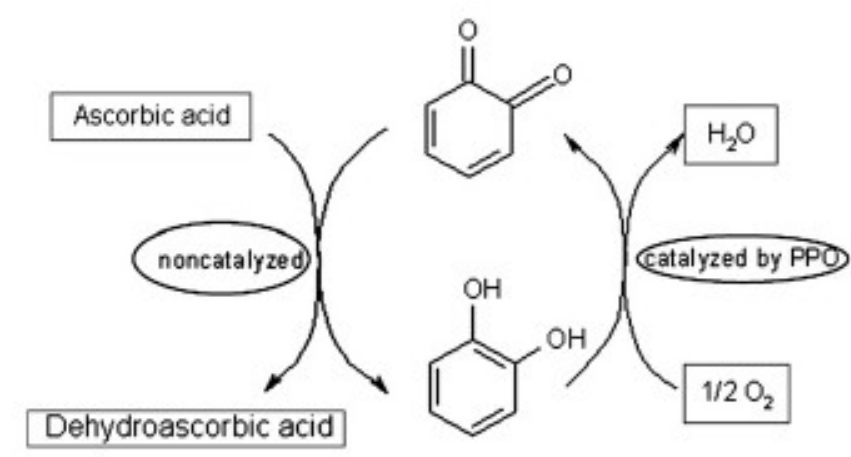

Fig. 1. Conversion of o-quinones to their precursor diphenols by the action of ascorbic acid (adapted from Walker, 1977).

\section{Calcium-based solutions}

Calcium treatments have been used to extend the shelflife of fruit and vegetables. Calcium helps to maintain the vegetable cell wall integrity by interacting with pectin to form calcium pectate. Calcium is reported to maintain firmness by cross-linking with cell wall and middle lamella pectins (Grant, Morris, Rees, Smith, \& Thom, 1973). Thus, fruit and vegetables treated with calcium generally remain firmer than controls during storage (Camire, Ismail, Work, Bushway, \& Halteman, 1994; Lester \& Grusak, 1999; Luna-Guzman et al., 1999; Martin-Diana et al., 2005, 2005a, 2005b; Rico et al., 2006; Suutarinen, Anakainen, \& Autio, 1999).

The use of calcium-based treatments has also been reported effective in reducing chlorophyll and protein loss and inhibiting plant tissue senescence (Lester \& Grusak, 1999; Poovaiah, 1986; Smout, Sila, Vu, Van Loey, \& Hendrickx, 2005). In apples it has been reported to reduce respiration and increase firmness retention as well as reducing in general the incidence of physiological disorder and decay (Bangerth, Dilley, \& Dewey, 1972; Dilley, 1990; Hewett \& Watkins, 1991).

Calcium lactate has been widely used for delicate fruit and products with a high senescence index, such as grapefruit (Baker, 1993), peaches (Manganaris, Vasilakakis, Diamantidis, \& Mignani, 2007), fresh-cut cantaloupes (Luna-Guzman \& Barrett, 2000) and apples (Anino, Salvatori, \& Alzamora, 2006; Buta, Moline, Spaulding, \& Wang, 1999). Calcium lactate $(0.5 \mathrm{e} 2 \%)$ has been used as a firming agent for fruit such as cantaloupes, strawberry and others (Main, Morris, \& Wehunt, 1986; Morris, Sistrunk, Sims, Main, \& Wehunt, 1985). It has been reported to be a good alternative to calcium chloride because it avoids the bitterness or off-flavours associated with this salt (Luna-Guzman \& Barret, 2000). Antibacterial properties have been reported for calcium propionate for the treatment of honeydew melon, due to its ability to uncouple microbial transport processes (Saftner et al., 2003).

Calcium lactate was tested as fresh-cut lettuce and carrots sanitiser and compared with chlorine (Martin-Diana et al., 2005a). As alternative to chlorine, calcium lactate showed no differences in affecting the quality of the 
product, and both treatments showed similar effectiveness in reducing and keeping the microbial load. The use of calcium-based treatments present a further advantage; in some cases the final product can significantly increase the calcium content (Anino et al., 2006), which might enhance the appreciation of these products, due to the fact that the awareness of consumers on the benefits of calcium is relatively high (Fig. 2).

\section{Ozone}

Ozone is a strong antimicrobial agent with high reactivity, penetrability and spontaneous decomposition to a non-toxic product (Grass, Vidal, Betoret, Chiralt, \& Fito, 2003; Kim, Yousef, \& Chism, 1999). Several researchers have shown that treatment with ozone appears to have a beneficial effect in extending the storage life of fresh non-cut commodities such as broccoli, cucumber, apples, grapes, oranges, pears, raspberries and strawberries by reducing microbial populations and by oxidation of ethylene (Beuchat et al.,1998; Kim et al., 1999; Skog \& Chu, 2001). The use of ozonated water has been applied to fresh-cut vegetables for sanitation purposes reducing microbial populations and extending the shelf-life of some of these products (Beltran, Selma, Marın, \& Gil, 2005, Beltran, Selma, Tudela, \& Gil, 2005). However, scarce information is currently available about inactivation of foodborne pathogens such as Shigella sonnei by ozone. Although the antimicrobial capacity of ozone has been widely reported, few studies in quality have been carried out (Baur, Klaiber, Hammes, \& Carle, 2004; Garcia, Mount, \& Davidson, 2003; Rico, Martin-Diana, Henehan, Frias, \& BarryRyan, 2006; Zhang, Zhaoxin, Zhifang, \& Xiang, 2005).

Ozone has been declared in many countries to have potential use for food processing and declared in the US as GRAS (FDA, 1997; Smilanick, Crisosto, \& Mlikota, 1999). It has a positive impact on water, decomposing many pesticides and reducing the oxygen demand (Guzel-Seydim, Greene, \& Seydim, 2004). In contact with organic matter, ozone creates aldehydes, ketones and carboxylic acids, causing less regulatory concern than chlorine (Guzel-Seydim et al., 2004). When compared to

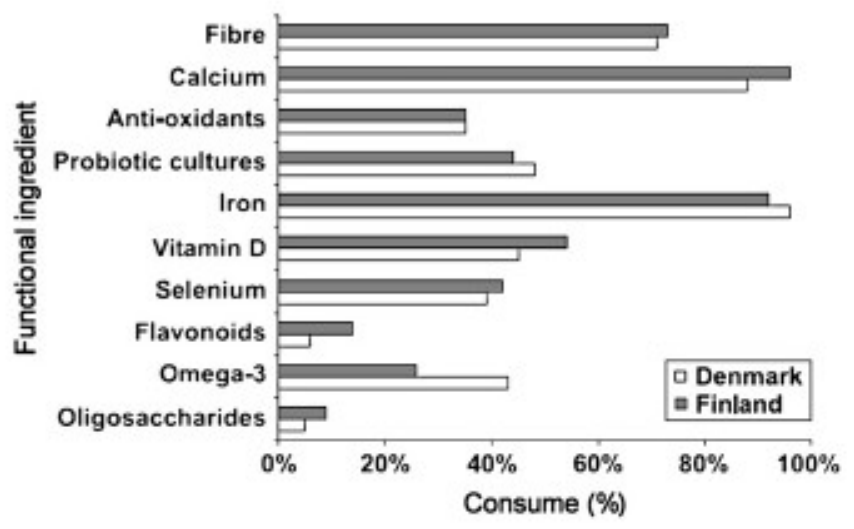

Fig. 2. Awareness of consumers on health effects of various functional ingredients (adapted from Menrad, 2003). chlorine, ozone has a greater effect against certain microorganisms and rapidly decomposes to oxygen, leaving no residues (White, 1992). However, a higher corrosiveness and initial capital cost for generator are the main disadvantages compared to the use of chlorine (Smilanick et al., 1999).

\section{Electrolysed water}

Electrolysed water (EW), also known as electrolysed oxidising water, is conventionally generated by electrolysis of aqueous sodium chloride to produce an electrolysed basic aqueous solution at the cathode and an electrolysed acidic solution at the anode (Kim, Hung, \& Brackett, 2000) (Fig. 3). Negatively charged ions, such as hydroxide ions and chloride ions in the salt solution, move to the anode to give up electrons and become oxygen gas, chlorine gas, hypochlorite ion, hypochlorous acid and hydrochloric acid, while positively charged ions such as hydrogen ions and sodium ions move to the cathode to take up electrons and become hydrogen gas and sodium hydroxide (Hsu, 2003).

Acidic EW (pH 2.1e4.5) has a strong bactericidal effect against pathogens and spoilage microorganisms, more effective than chlorine due to a high oxidation reduction potential (ORP) (Bari, Sabina, Isobe, Uemura, \& Isshiki, 2003) and has shown higher effectiveness in reducing viable aerobes than ozone on whole lettuce (Koseki, Yoshida, Isobe, \& Itoh, 2001) although at expense of produce quality when used on fresh-cut vegetables (Wang, Feng, \& Luo, 2004).

Different works have shown that the use of EW inactivates Staphylococcus aureus, Pseudomonas aeruginosa,

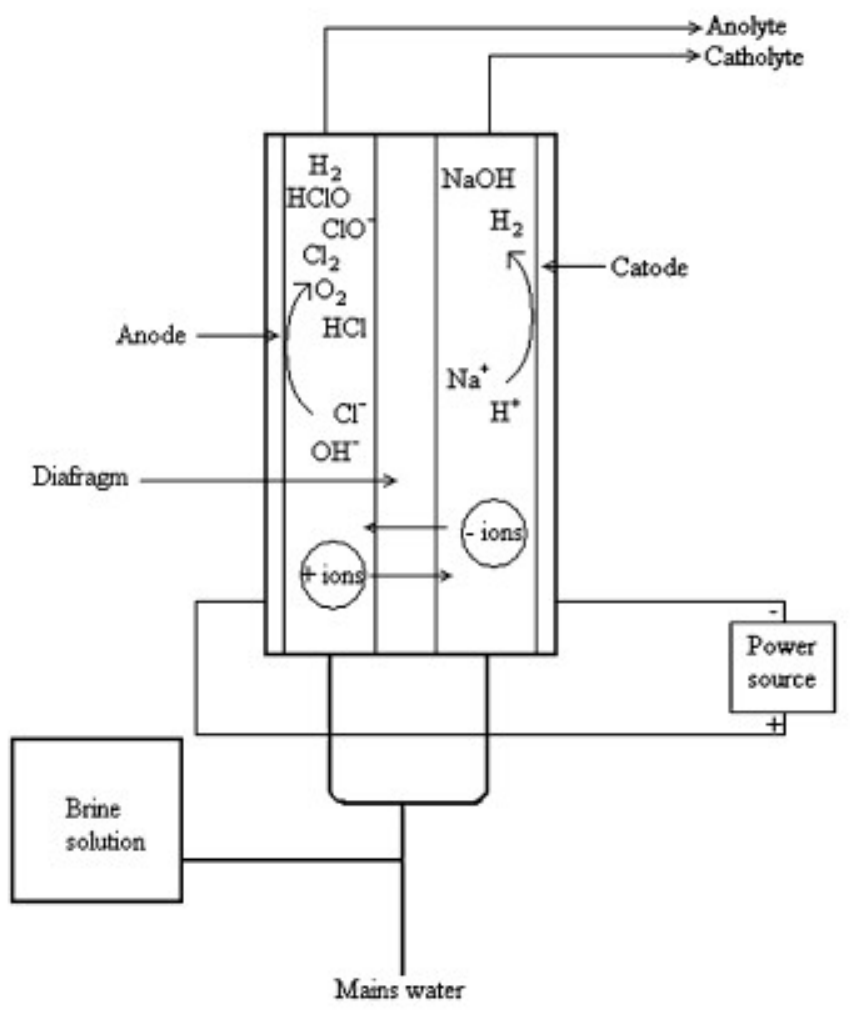

Fig. 3. Electrolysed water production (adapted from Hsu, 2003). 
Enterococcus sp., Aeromonas sp. E. coli and Legionella pneumophila. But also microorganisms of agricultural importance such as Bacillus subtilis, Ralstonia solanacearum, Rhizoctonia solani, Pythium ultimum, Fusarium oxysporum f.sp. Iycopersici and Trichoderma hamatum (Polanska, 2001). Furthermore, the use of EW neutralises harmful substances such as cyanides, ammonium, etc.

Otherwise, the disinfectant properties of EW solutions with higher $\mathrm{pH}$ (w7) have been tested by Izumi (1999) showing no adverse effects on surface colour, $\mathrm{pH}$ or general appearance of fresh-cut vegetables. The use of neutral EW offers the advantage over acidic EW that the first does not affect the $\mathrm{pH}$, surface colour or general appearance of the product treated (Izumi, 1999). A few studies have been reported in fresh-cut vegetables (Izumi, 1999; Martın-Diana et al., in press; Ongeng et al., 2006; Wang et al., 2004) and the major emphasis is focused on microbial aspects with relatively little attention to quality (browning, texture, etc.).

Natural preservatives for treating minimally processed fruit and vegetables

Concern caused by traditional food preservatives, reporting of occasional allergic reactions in sensitive individuals and the formation of potentially carcinogenic by-products (e.g. nitrosamines from nitrite) among other problems, has increased the interest in antimicrobial compounds found in nature and the demand from consumers, especially in Europe (Roller, 2003). Minimally processed fruit and vegetables industry is aware of consumer trends and aims to avoid the use of chemical preservatives (Meyer, Suhr, $\&$ Nielsen, 2002). The use of natural preservatives may be effective to retain quality of minimally processed products by having an antimicrobial effect, inhibiting spoilage or avoiding oxidative processes.

Natural antimicrobials can be defined as substances produced by living organisms in their fight with other organisms for space and their competition for nutrients. The main sources of these compounds are plants (e.g. plant secondary metabolites in essential oils and phytoalexins), microorganisms (e.g. bacteriocins and organic acids) and animals (e.g. lysozyme from eggs and transferrins from milk) (Meyer et al., 2002).

Other options for obtaining natural preservative sources are by-products from different processing industries. Research and commercial applications have shown natural antimicrobials from these sources could replace traditional sanitising agents (Cherry, 1999).

Whey permeate (WP) is a by-product of the cheese industry with potential as a sanitising agent. Approximately $9 \mathrm{~kg}$ of whey is produced for every kilogram of cheese manufactured. The high chemical oxygen demand (COD) (50 $\mathrm{kg} \mathrm{O}_{2} /$ ton permeate) of whey makes its disposal a significant pollution problem. In order to maximise profits and minimise environmental impact different uses for this waste material have been devised by the dairy industry. The use of whey as a fermentation feedstock has long been of industrial interest for the production of lactic acid, acetic acid, propionic acid, ethanol, and single cell protein (Bogaert, 1997; Martın-Diana et al., 2006; Tyagi \& Kluepfel, 1998). However, these applications still do not utilize all the whey produced and new uses for this by-product are continually being sought.

The antimicrobial potential of the WP might be due to some of the following characteristics: low $\mathrm{pH}$ and the presence of lactic acid and thermo-resistant bacteriocins and other small bio-active peptides (Nykanen, Lapvetelainen, Hietnen, \& Kallio, 1998). The use of WP for food preservation has been examined by Nykanen et al. (1998). These authors analysed the effect of WP washing solutions on total microbial counts and sensory characteristics of rainbow trout. They found that WP treatment gave a reduction in total counts and had no negative effect on sensory attributes. No studies on application of WP as a decontaminant agent on fruit and vegetables have been carried out to date. Preliminary studies reported by Martın-Diana et al. (2006) with whey permeate in fresh-cut products showed a good antimicrobial activity. These authors observed an important effect of concentration of WP in the control of microbial growth. Newer tendency has been reported by Bari et al. (2005), who combined the efficacy of chemical disinfectant with the antimicrobial effect of bacteriocins produced by lactic acid bacteria. They investigated the efficacy of nisin and pediocin treatments in combination with EDTA, citric acid, sodium lactate, potassium sorbate and phytic acid in reducing $L$. monocytogenes. They concluded that pediocin and nisin applications in combination with organic acids caused a significant reduction of native microflora and inoculated populations on fresh produce.

Physical treatments for minimally processed fruit and vegetables

Modified atmosphere packaging

Modified atmosphere packaging (MAP) is a preservation technique already in use by the fresh-cut industry. It implies altering the gases surrounding a commodity to produce a composition different from that of air (Al-Ati \& Hotchkiss, 2002). Low levels of $\mathrm{O}_{2}$ and high levels of $\mathrm{CO}_{2}$ reduce the produce respiration rate, with the benefit of delaying senescence, thus extending the storage life of the fresh produce (Saltveit, 1993).

The modified atmosphere can be achieved passively (the package is sealed under normal air conditions) or actively (the package is flushed with a gas mixture before closed). Once the package is closed, no further control of the gas composition is exercised, and the composition will inevitably change due to produce respiration and film gas permeability (Sivertsvik, Rosnes, \& Bergslien, 2002). Excessively low levels of $\mathrm{O}_{2}$ favour fermentative processes which might cause the formation of acetaldehyde and the appearance of off-flavours compounds (Kays, 1991). The atmosphere concentrations recommended for preservation depend on the product. In general, fresh-cut products are more tolerant 
to higher $\mathrm{CO}_{2}$ concentrations than intact products, because the resistance to diffusion is smaller (Kader et al., 1989). Lettuce is not tolerant to $\mathrm{CO}_{2}$, but shredded lettuce can tolerate concentrations from 10 to 15\% (Fonseca, Oliveira, Brecht, \& Chau, 1999).

The potential of MAP to extend shelf-life for many foods has been well documented (Brecht, Chau, Fonseca, \& Oliveira, 2003; Jacxsens, Devlieghere, \& Debevere, 2001; Saltveit, 2003). However, there is still a major concern about the product safety associated with the use of MAP, mainly due to the desired suppression of spoilage microorganisms which extends the shelf-life if compared to food products stored in a normal air environment, and this may create opportunities for slower growing pathogenic bacteria (Rosnes, Sivertsvik, \& Skara, 2003).

Thermal treatments. Blanching and heat-shock

Thermal methods are extensively used for the preservation and preparation of foods. These treatments lead to undesirable changes such as loss of vitamins and minerals, formation of thermal reaction components of biopolymers and, in minimal processing terms, loss of fresh appearance, flavour and texture.

The classical approach to overcome, or at least minimise, these undesirable quality changes in thermal processing is the high temperature short time (HTST) concept. It is based on the fact that the inactivation of microorganisms primarily depends on the temperature of the heat treatment, whereas many undesirable quality changes depend primarily on the duration time of the heat treatment (Ohlsson, 1980). High temperatures will give the rapid inactivation of microorganisms and enzymes required in pasteurisation or sterilisation, and short times will give fewer undesired quality changes. Effective process control is critical if product quality is not to be compromised (Ohlsson, 2002).

The use of blanching as a decontaminant treatment operation in the minimally processed vegetable industries is well established (Arroqui, Lopez, Esnoz, \& Virseda, 2003). Blanching consists in heating at high temperature, generally in water at $85 \mathrm{e} 100 \mathrm{C}$ or with steam, less frequently with microwaves, radiofrequency or infrared radiation. Short times of exposure are effective to reduce the incidence of degradation reactions during storage.

Blanching not involving any chemical treatment can reduce initial mesophilic counts of leafy salads by more than 3-log cfu/g and Enterobacteriaceae counts by less than 1-log cfu/g (Gartner, Mayer-Miebach, \& Spiess, 1997). However, blanching itself introduces deleterious changes in the product by the loss of nutrients through thermal degradation, diffusion and leaching, increases power consumption and generates effluents (Negi \& Roy, 2000; Song, An, \& Kim, 2003). Texture and colour can be affected by blanching, but if it is applied previously to minimal processing, can help to preserve colour, as it has been shown with strawberries
(Moreno, Chiralt, Escriche, \& Serra, 2000), by inactivation of polyphenoloxidase.

Heat-shock is a HTST method which usually implies a washing step at a temperature ranging $45 \mathrm{e} 70 \mathrm{C}$ for a few minutes, usually less than 5 min (Hisaminato et al., 2001; Loaiza-Velarde et al., 1997). This way, heat-shock can be very useful as a quality preservation agent. Loaiza-Velarde et al. (1997) reported that heat-shock treatment at 50e60 C repressed the enzymatic browning of cut lettuce. Murata et al. (2004) also reported heat-shock prevented the browning in fresh-cut lettuce, repressing the accumulation of phenolics and also improved organoleptic properties of the vegetable. In tissue with initial low levels of preformed phenolic compounds (e.g. celery, lettuce) browning results from the induced synthesis and subsequent accumulation of phenolic compounds. A heat-shock treatment that reduces browning in fresh-cut lettuce (e.g. $90 \mathrm{~s}$ at $45 \mathrm{C}$ ) may work by redirecting protein synthesis away from the production of wound-induced enzymes of phenolic metabolism, and toward the production of innocuous heat-shock proteins (HSPS) (Martin-Diana et al., 2005; Saltveit, 2000). Administering the heat-shock up to $24 \mathrm{~h}$ before, or $8 \mathrm{~h}$ after wounding significantly reduced the wound-induced increase in phenylalanine ammonialyase (PAL) activity, the accumulation of phenolic compounds, and the subsequent browning of excised lettuce leaf tissue (Fig. 4) (Loaiza-Velarde \& Saltveit, 2001; Saltveit \& Loaiza-Velarde, 2000).

Heat-shock prevents quality deterioration, helping to maintain texture and colour qualities longer. Therefore, there is a necessity of combining this heat-shock with a sanitising method, such as washing with chlorine or an alternative antimicrobial agent, e.g. calcium lactate. Other methods for the application of heat to products are infrared

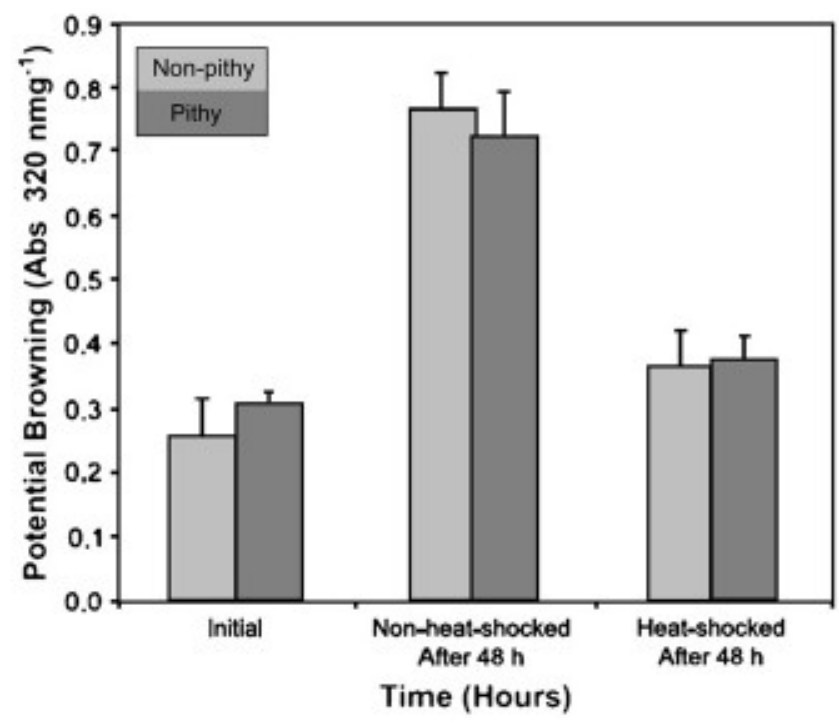

Fig. 4. Effect of wounding and heat-shock on the potential browning of fresh-cut celery (adapted from Loaiza-Velarde, Mangrich, Campos-Vargas, \& Saltveit, 2003). 
radiation and electric heating. Infrared radiation has been tested as a minimal heat process before freezing carrots (Gomez-Galindo, Toledo, \& Sjoholm, 2005). Electric heating directly heats the whole volume of the food and is a method that may overcome HTST limitations caused by the low heat diffusivity of foods (Ohlsson, 1994; Orsat, Gariepy, Raghavan, \& Lyew, 2001).

Irradiation

Low-dose gamma irradiation is very effective reducing bacterial, parasitic, and protozoan pathogens in raw foods. Irradiation was approved by the FDA for use on fruit and vegetables at a maximum level of $1.0 \mathrm{kGy}$ (IFT, 1983). In some instances, the produce quality is extended while in others it results in a loss of quality attributes. The irradiation of minimally processed carrots improved their colour and flavour, although impaired the texture (Chervin \& Boisseau, 1994). In minimally processed lettuce, doses of up to $0.5 \mathrm{kGy}$ have been proved not to affect quality, and depending on the authors, quality was affected at irradiation levels of 0.81 or $1.1 \mathrm{kGy}$ (Foley, Euper, Caporaso, \& Prakash, 2004; Goularte et al., 2004; Hagenmaier \& Baker, 1997; Niemira, Sommers, \& Fan, 2002). Microbiological studies carried out in Cantaloupes (Boyntonet al., 2006) showed than samples irradiated had a lower and more stable rate of respiration than non-irradiated samples over about 20 days and total plate counts were significantly higher in non-irradiated control samples through storage.

\section{Ultraviolet light}

Ultraviolet light (UV) acts as an antimicrobial agent directly due to DNA damage (Rame, Chaloupecky, Sojkova, \& Bencko, 1997) and indirectly due to the induction of resistance mechanisms in different fruit and vegetables against pathogens (Liu et al., 1993; Nigro, Ippolito, \& Lima, 1998). Exposure to UV also induces the synthesis of health-promoting compounds such as anthocyanins and stilbenoids (Cantos, Espin, \& Tomas-Barberan, 2001). Another advantage of this technique is the relatively inexpensive and easy-to-use equipment needed (Bintsis, Litopoulou-Tzanetaki, \& Robinson, 2000).

However, high UV doses can cause damage to the treated tissue as previously described by Ben-Yehoshua, Rodov, Kim, and Carmeli (1992) and Nigro et al. (1998). Allende and Artes (2003a) studied the use of UltravioletC (254 nm, UV-C) on minimally processed lettuce, showing this technique can reduce deterioration of the produce by effectively reducing microbial populations. But negative effects were also found, and the application of UV-C increased the stress of the produce, respiration rate, and possibly induced a lignification-like process, which changed the appearance of the samples.

\section{High pressure processing}

By subjecting foods to high pressures in the range 3000 e 8000 bars, microorganisms and enzymes can be inactivated without the degradation in flavour and nutrients associated with traditional thermal processing (Palou, Lopez-Malo, Barbosa-Canovas, \& Welti-Chanes, 2000). There are some problems associated with its use on vegetables, as it affects the integrity of porous products. The air confined in the food matrix is subjected to compression and expansion during pressurization and decompression, disrupting food tissues, therefore making this unit operation unsuitable for fresh vegetables (Palou et al., 2000).

\section{Hurdle technology}

Hurdle technology is the combination of different preservation techniques as a preservation strategy. The most important hurdles commonly used in food preservation are based on controlling temperature, water activity, acidity, redox potential and the use of preservatives, modified atmosphere and competitive microorganisms (e.g., lactic acid bacteria) (Leistner, 1999). By combining hurdles, the intensity of the individual preservation techniques can be kept comparatively low, minimising the loss of quality, while the overall impact on microbial growth may remain high (Gorris \& Tauscher, 1999). The selection of hurdles needs to be tailored carefully to the quality attributes of a product (Gorris \& Tauscher, 1999). According to Leistner (1999), there are more than 60 potential hurdles for foods that improve the stability and/or quality of minimally processed products. Examples of hurdles technologies are the natural preservatives, which are used as hurdles in food deterioration but more systematic studies on multi-synergistic effects are scarce in real food systems, e.g. combining lactoferrin, organic acids and oregano extracts with modified atmosphere packaging and pulsed electric field technology to prevent microbial growth mainly.

\section{Conclusions}

Ready-to-eat fruit and vegetable market has grown rapidly in recent years due to the health benefits associated with these foods. Its growth has heightened awareness about the microbiological and physiological parameters associated with quality in fresh ready-to-eat vegetables due to the relevance for industry and its economic impact. Most of the alternative techniques to chlorine reviewed in this paper have not yet been adopted by the fresh-cut industry. Chlorine continues being the most commonly used sanitiser due to its efficacy, cost-effectiveness ratio and simple use. However, new stricter regulations on the use of chlorine urge fresh-cut industry to find new alternatives. These alternatives must satisfy the consumers and maintain a balance between sensory and quality. For this reason exploration and enhancement of new alternatives are essential.

\section{Acknowledgements}

This research was supported by a Technological Sector Research Grant (2002e2006) and International Collaboration Award Scheme (ICAS) (2005e2007). Authors acknowledge Elsevier publications for the permission to reproduce parts of figures and tables for this review. 


\section{References}

Adams, J. B. (1991). Enzyme inactivation during heat processing of food-stuffs. International Journal of Food Science and Technology, 26, $1 \mathrm{e} 20$.

Adams, M. R., Hartley, A. D., \& Cox, L. J. (1989). Factors affecting the efficacy of washing procedures used in the production of prepared salads. Food Microbiology, 6, 69e77.

Aguilera, J. M. (2005). Why food microstructure? Journal of Food Engineering, 67, 3e11.

Ahvenainen, R. (1996). New approaches in improving the shelf life of minimally processed fruits and vegetables. Trends in Food Science and Technology, 7, 179e186.

Al-Ati, T., \& Hotchkiss, J. H. (2002). Application of packaging and modified atmosphere to fresh-cut fruits and vegetables. In O. Lamikanra (Ed.), Fresh-cut fruits and vegetables. Science, technology and market. Boca Raton, FL: CRC Press.

Allende, A., \& Artes, F. (2003a). UV-C radiation as a novel technique for keeping quality of fresh processed 'Lollo Rosso' lettuce. Food Research International, 36, 739e746.

Allende, A., \& Artes, F. (2003b). Combined ultraviolet-C and modified atmosphere packaging treatments for reducing microbial growth of fresh processed lettuce. Food Science and Technology, 36, 779e786.

Anino, S. V., Salvatori, D. M., \& Alzamora, S. M. (2006). Changes in calcium level and mechanical properties of apple tissue due to impregnation with calcium salts. Food Research International, 39, $154 \mathrm{e} 164$.

Arroqui, C., Lopez, A., Esnoz, A., \& Virseda, M. P. (2003). Mathematical model of heat transfer and enzyme inactivation in an integrated blancher cooler. Journal of Food Engineering, 58(3), $215 \mathrm{e} 225$.

Babic, I., Amiot, M. J., Nguyen-the, C., \& Aubert, S. (1993). Changes in phenolic content in fresh ready-to-use shredded carrots during storage. Journal of Food Science, 58, 351e356.

Baker, R. A. (1993). Firmness of canned grapefruit sections improved with calcium lactate. Journal of Food Science, 58, 1107e1110.

Bangerth, F., Dilley, D. R., \& Dewey, D. H. (1972). Effect of postharvest calcium treatments on internal breakdown and respiration of apple fruits. Journal of the American Society of Horticultural Science, 97, 679e682.

Bari, M. L., Sabina, Y., Isobe, S., Uemura, T., \& Isshiki, K. (2003). Effectiveness of electrolyzed acidic water in killing Escherichia coli O157:H7, Salmonella enteridis, and Listeria monocytogenes on the surfaces of tomatoes. Journal of Food Protection, 66 $542 \mathrm{e} 548$

Bari, M. L., Ukuku, D. O., Kawasaki, T., Inatsu, Y., Isshiki, K., \& Kawamoto, S. (2005). Combined efficacy of nisin and pediocin with sodium lactate, citric acid, phytic acid, and potassium sorbate and EDTA in reducing the Listeria monocytogenes population of inoculated fresh-cut produce. Journal of Food Protection, 68, 1381e1387.

Barry-Ryan, C., \& O'Beirne, D. (1999). Ascorbic acid retention in shredded Iceberg lettuce as affected by minimal processing. Journal of Food Science, 64(3), 498e500.

Bauernfeind, J. C., \& Pinkert, D. M. (1970). Food processing with added ascorbic acid. Advances in Food Research, 18, 219e315.

Baur, S., Klaiber, R., Hammes, W. P., \& Carle, R. (2004). Sensory and microbiological quality of shredded, packaged iceberg lettuce as affected by pre-washing procedures with chlorinated and ozonated water. Innovative Food Science and Emerging Technologies, $5,45 e 55$

Baur, S., Klaiber, R., Wei, H., Hammes, W. P., \& Carle, R. (2005). Effect of temperature and chlorination of pre-washing water on shelf-life and physiological properties of ready-to-use iceberg lettuce. Innovative Food Science and Emerging Technologies, 6, 171e182.

Beltran, D., Selma, M. V., Marın, A., \& Gil, M. I. (2005). Ozonated water extends the shelf life of fresh-cut lettuce. Journal of Agricultural and Food Chemistry, 53, 5654e5663.
Beltran, D., Selma, M. V., Tudela, J. A., \& Gil, M. I. (2005). Effect of different sanitizers on microbial and sensory quality of fresh-cut potato strips stored under modified atmosphere or vacuum packaging. Postharvest Biology and Technology, 37, 37e46.

Ben-Yehoshua, S., Rodov, V., Kim, J. J., \& Carmeli, S. (1992). Preformed and induced antifungal materials of citrus fruits in relation to the enhancement of decay resistance by heat and ultraviolet treatments. Journal of Agricultural Food Chemistry, 40, $1217 \mathrm{e} 1221$.

Benarde, M. A., Israel, B. M., Oliveri, V. P., \& Granstrom, M. L. (1965). Efficiency of chlorine dioxide as a bactericide. Journal of Applied Microbiology, 13, 776.

Beuchat, L. F. (2000). Use of sanitizers in raw fruit and vegetable processing. In S. M. Alzamora, M. S. Tapia, \& A. Lopez-Malo (Eds.), Minimally processed fruits and vegetables (pp. 63e78). Maryland: Aspen.

Beuchat, L. R. (1992). Surface disinfection of raw produce. Dairy, Food and Environmental Sanitation, 12, 6e9.

Beuchat, L. R. (1996). Pathogenic organisms associated with fresh produce. Journal of Food Protection, 59(2), 204e216.

Beuchat, L. R. (1999). Survival of enterohemorrhagic Escherichia coli O157:H7 in bovine feces applied to lettuce and the effectiveness of chlorinated water as a disinfectant. Journal of Food Protection, 62(8), 845e849.

Beuchat, L. R., Nail, B. V., Adler, B. B., \& Clavero, M. R. S. (1998). Efficacy of spray application of chlorine in killing pathogenic bacteria on raw apples, tomatoes, and lettuce. Journal of Food Protection, 61, 1305e1311.

Beuchat, L. R., \& Ryu, J. H. (1997). Produce handling and processing practices: special issue. Emerging Infectious Diseases, 3(4), $459 \mathrm{e} 465$.

Bintsis, T., Litopoulou-Tzanetaki, E., \& Robinson, R. K. (2000). Existing and potential applications of ultraviolet light in the food industry $\mathrm{e}$ a critical review. Journal of the Science of Food and Agriculture, 80,637 e645.

Bogaert, J. C. (1997). Production and novel applications of natural L(p) lactic acid: food pharmaceutics and biodegradable polymers. Cerevis, 22, 46e50.

Bolin, H. R., \& Huxsoll, C. C. (1991). Control of minimally processed carrot (Dacus carota) surface discoloration caused by abrasion peeling. Journal of Food Science, 56, 416e418.

Bolin, H. R., \& Huxsoll, C. C. (1991). Effect of preparation procedures and storage parameters on quality retention of salad-cut lettuce. Journal of Food Science, 56, 60e67.

Bottcher, H., Ghunter, I., \& Kabelitz, L. (2003). Physiological postharvest responses of Common Saint-John's wort herbs (Hypericum perforatum, L.). Postharvest Biology and Technology, 29, $342 \mathrm{e} 350$.

Bourne, M. (2002). Food texture and viscosity. Food echnology, International Series, (2nd ed.). San Diego, CA: Academic Press.

Boynton, B. B., Welt, B. A., Sims, C. A., Balaban, M. O., Brecht, J. K., \& Marshall, M. R. (2006). Effects of low-dose electron beam irradiation on respiration, microbiology, texture, color, and sensory characteristics of fresh-cut Cantaloupe stored in modifiedatmosphere. Journal of Food Science, 71, 149e155.

Brackett, R. E. (1999). Incidence, contributing factors, and control of bacterial pathogens in produce. Postharvest Biology and Technology, 15, 305e311.

Brecht, J. K. (1995). Physiology of lightly processed fruits and vegetables. Horticultural Science, 301, 8e22.

Brecht, J. K., Chau, K. V., Fonseca, S. C., \& Oliveira, F. A. R. (2003). CA transport of fresh produce in MAP: designing systems for optimal atmosphere conditions throughout the postharvest handling chain. Acta Horticulturae, 600(2), $799 \mathrm{e} 801$.

Bruhn, C. (2000). Food labelling: consumer needs. In J. Ralph Blanchfield (Ed.), Food labelling. Cambridge: Woodhead Publishing Limited. 
Buta, J. G., Moline, H. E., Spaulding, D. W., \& Wang, C. Y. (1999) Stending storage life of fresh-cut apples using products and their derivatives. Journal of Agricultural and Food Chemistry, 47, $1 \mathrm{e} 6$.

Camire, E. M., Ismail, S., Work, T. M., Bushway, A. A., \& Halteman, W. A. (1994). Improvements in canned lowbush blueberry quality. Journal of Food Science, 59, 394e398.

Cantos, E., Espin, J. C., \& Tomas-Barberan, F. A. (2001). Effect of wounding on phenolic enzymes in six minimally processed lettuce cultivars upon storage. Journal of Agricultural and Food Chemistry, 49(1), 22e30.

Carlin, F., \& Nguyen-the, C. (1999). Minimally processed producemicrobiological issues. In Proceedings of the international conference on fresh-cut produce, Chipping Camden, 9-10 September 1999. Chipping Campden, UK: Campden \& Chorleywood Food Research Association (CCFRA).

Chang, C. Y., Liao, H. J., \& Wu, T. P. (1996). Relationships between the textural changes and the contents of calcium, magnesium ions, and non-freezing water in the alcohol-insoluble solids of snap bean pods during cooking processes. Food Chemistry, 55, 49e53.

Cherry, J. P. (1999). Improving the safety of fresh produce with antimicrobials. Food Technology, 53, 54e59.

Chervin, C., \& Boisseau, P. (1994). Quality maintenance of readyto-eat shredded carrots by gamma irradiation. Journal of Food Science, 59, 359e362.

Cisneros-Zevallos, L., Saltveit, M., \& Krochta, J. (1997). Hygroscopic coating control surface white discoloration of peeled (minimally processed) carrots during storage. Journal of Food Science, 62, $363 e 367$.

Clydesdale, F. M. (1993). Color as a factor in food choice. Critical Reviews in Food Science and Nutrition, 33(1), 83e101.

Couture, R., Cantwell, M. I., Ke, D., \& Saltveit, M. E. (1993). Physiological attributes and storage life of minimally processed lettuce. Hortscience, 28, 723e725.

Del Nobile, M. A., Baiano, A., Benedetto, A., \& Massignan, L. (2006). Respiration rate of minimally processed lettuce as affected by packaging. Journal of Food Engineering, 74, 60e69.

Dilley, D. R. (1990). Increasing the calcium content of apple fruits to improve storability and attenuate physiological disorders Annual Report of the Michigan State Horticultural Society, 120, $195 \mathrm{e} 207$.

Eskin, M. N. A. (1990). Biochemical changes in raw foods: fruits and vegetables. In M. N. A. Eskin (Ed.), Biochemistry of foods (pp. 70e78). Toronto, ON: Academic Press.

Fillion, L., \& Kilcast, D. (2002). Consumer perception of crispiness and crunchiness in fruits and vegetables. Food Quality and Preference, $13,23 e 29$

Foley, D., Euper, M., Caporaso, F., \& Prakash, A. (2004). Irradiation and chlorination effectively reduces Escherichia coli O157:H7 inoculated on cilantro (Coriandrum sativum) without negatively affecting quality. Journal of Food Protection, 67, 2092e2098.

Fonseca, S. C., Oliveira, F. A. R., Brecht, J. K., \& Chau, K. V. (1999). Development of perforation-mediated modified atmosphere packaging for fresh-cut vegetables. In F. A. R. Oliveira, \& J. C. Oliveira (Eds.), Processing foods. Quality optimization and process assessment (pp. 389e404). New York: Boca Raton.

Food and Drug Administration (FDA) (1997). Substances generally recognized as safe, proposed rule. Federal Register, 62(74), 18937 e18964.

Food and Drug Administration (FDA). (1998). Department of health and human services. Secondary Direct Food Additive for Human Consumption. 21 CFR. Part 173.300 chlorine dioxides.

Francis, G. A. \& O'Beirne, D. (2002). Effects of vegetable type and antimicrobial dipping on survival and growth of Listeria innocua and E. coli. International Journal of Food Science and Technology, 37(6), 711.
Francis, G. A., Thomas, C., \& O'Beirne, D. (1999). The microbiological safety of minimally processed vegetables. International Journal of Food Science \& Technology, 34, 1e22.

Garcia, A., Mount, J. R., \& Davidson, P. M. (2003). Ozone and chlorine treatment of minimally processed lettuce. Food Microbiology and Safety, 68(9), 2747e2751.

Garcia, E., \& Barrett, D. M. (2002). Preservative treatments for freshcut fruits and vegetables. In O. Lamikanra (Ed.), Fresh-cut fruits and vegetables. Science, technology and market. Boca Raton, FL: CRC Press.

Gartner, U., Mayer-Miebach, E., \& Spiess, W. E. L. (1997). Controlling the microbial load on ready-to-use sliced salads by lowtemperature blanching. In R. Jowitt (Ed.), Engineering and food at ICEF 7 (pp. J41eJ42). Sheffield: Sheffield Academic Press.

Gil, M. I., Ferreres, F., \& Tomas-Barberan, F. A. (1999). Effect of postharvest storage and processing on the antioxidant constituents (Flavonoids and Vitamin C) of fresh-cut spinach. Journal of Agricultural and Food Chemistry, 47, $2213 e 2217$.

Gomez-Galindo, F., Toledo, R. T., \& Sjoholm, I. (2005). Tissue damage in heated carrot slices. Comparing mild hot water blanching and infrared heating. Journal of Food Engineering, 67 $381 \mathrm{e} 385$.

Gorris, L. G. M., \& Tauscher, B. (1999). Quality and safety aspects of novel minimal processing technologies. In F. A. R. Oliveira, \& J. C. Oliveira (Eds.), Processing foods. Quality optimization and process assessment (pp. 325e339). New York: Boca Raton.

Goularte, L., Martins, C. G., Morales-Aizpurua, I. C., Destro, M. T. Franco, B. D. G. M., Vizeu, D. M., et al. (2004). Combination of minimal processing and irradiation to improve the microbiological safety of lettuce (Lactuca sativa, L.). Radiation Physics and Chemistry, 71, 157e161.

Grant, G. T., Morris, E. R., Rees, D. A., Smith, P. J. C., \& Thom, D. (1973). Biological interactions between polysaccharides and divalent cations: the egg-box model. FEBS Letters, 32, 195e198.

Grass, M. L., Vidal, D., Betoret, N., Chiralt, A., \& Fito, P. (2003). Calcium fortification of vegetables by vacuum impregnation interactions with cellular matrix. Journal of Food Engineering, 56, 279e284.

Guzel-Seydim, Z. B., Greene, A. K., \& Seydim, A. C. (2004). Use of ozone in the food industry. LWT Food Science and Technology, $37,453 \mathrm{e} 460$.

Hagenmaier, R. D., \& Baker, R. A. (1997). Low-dose irradiation of cut iceberg lettuce in modified atmosphere packaging. Journal of Agricultural and Food Chemistry, 45, 2864e2868.

Hahlbrock, K., \& Scheel, D. (1989). Physiology and molecular biology of phenylpropanoid metabolism. Annual Review in Plant Physiology and Plant Molecular Biology, 40, 347e369.

Han, J., Gomes-Feitosa, C. L., Castell-Perez, E., Moreira, R. G., \& Silva, P. F. (2004). Quality of packaged romaine lettuce hearts exposed to low-dose electron beam irradiation. LWT Food Science and Technology, 37, 705e715.

Han, Y., Guentert, A. M., Smith, R. S., Linton, R. H., \& Nelson, P. E. (1999). Efficacy of chlorine dioxide gas as a sanitizer for tanks used for aseptic juice storage. Food Microbiology, 16, 53e61.

Han, Y., Sherman, D. M., Linton, R. H., Nielsen, S. S., \& Nelson, P. E. (2000). The effects of washing and chlorine dioxide gas on survival and attachment of Escherichia coli O157:H7 to green pepper surfaces. Food Microbiology, 57, 521e533.

Harker, F. R., Stec, M. G. H., Hallett, I. C., \& Bennett, C. L. (1997). Texture of parenchymatous plant tissue: a comparison between tensile and other instrumental and sensory measurements of tissue strength and juiciness. Postharvest Biology and Technology, 11, 63e72.

Hewett, E. W., \& Watkins, C. B. (1991). Bitter pit control by sprays and vacuum infiltration of calcium in "Cox's Orange Pippin" apples. Hort-Science, 26, 284e286.

Hisaminato, H., Murata, M., \& Homma, S. (2001). Relationship between enzymatic browning of cut lettuce and phenylalanine ammonia-lyase activity, and prevention of browning by inhibitors 
of polyphenol biosynthesis. Bioscience, Biotechnology and Biochemistry, 65, 1016e1021.

Howard, L. R., \& Dewi, T. (1996). Minimal processing and edible coating effects on composition and sensory quality of mini-peeled carrots. Journal of Food Science, 61, 643e645.

Howard, L. R., \& Griffin, L. E. (1993). Lignin formation and surface discoloration of minimally processed carrot sticks. Journal of Food Science, 58, 1065e1067.

Howard, L. R., Griffin, L. E., \& Lee, Y. (1994). Steam treatment of minimally processed carrot sticks to control surface discoloration. Journal of Food Science, 59, 356e358.

Hsu, S. Y. (2003). Effects of water flow rate, salt concentration and water temperature on efficiency of an electrolyzed oxidizing water generator. Journal of Food Engineering, 60, 469e473.

IFT. (1983). Radiation preservation of foods. A scientific status summary by the institute of food technologists' expert panel on food safety and nutrition, Chicago, III. Food Technology, 37(2), $55 \mathrm{e} 61$.

Ihl, M., Aravena, L., Scheuermann, E., Uquiche, E., \& Bifani, V. (2003). Effect of immersion solutions on shelf-life of minimally processed lettuce. LWT Food Science and Technology, 36, 591e599.

Izumi, H. (1999). Electrolysed water as a disinfectant for fresh-cut vegetables. Journal of Food Science, 64, 536e539.

Jacxsens, L., Devlieghere, F., \& Debevere, J. (2001). Effect of high oxygen modified atmosphere packaging on microbial growth and sensorial qualities of fresh-cut produce. International Journal of Food Microbiology, 71, 197e210.

Juven, B., \& Pierson, M. D. (1996). Antibacterial effects of hydrogen peroxide and methods for its detection and quantitation. Journal of Food Protection, 59(11), 1233e1241.

Kabir, H. (1994). Fresh-cut vegetables. In A. L. Brods, \& V. A. Herndon (Eds.), Modified atmosphere food packaging (pp. 155e160) Naperville, Illinois: Institute of Packaging Professionals.

Kader, A. A. (2002). Quality parameters of fresh-cut fruit and vegetable products. In O. Lamikanra (Ed.), Fresh-cut fruits and vegetables. Science, echnology and arket. Boca Raton, FL: CRC Press.

Kader, A. A., Zagory, E. L., \& Kerbel, E. L. (1989). Modified atmosphere packaging of fruit and vegetables. CRC Critical Reviews in Food Science and Nutrition, 28, 1e30.

Kang, H. M., \& Saltveit, M. E. (2002). Antioxidant capacity of lettuce leaf tissue increases after wounding. Journal of Agricultural and Food Chemistry, 50, 7536e7541.

Kaur, C., \& Kapoor, H. C. (2001). Antioxidants in fruits and vegetables e the millennium's health. International Journal of Food Science and Technology, 36, 703e725.

Kays, S. J. (1991). Postharvest physiologycal of perishable plant products. New York: Van Nostrand Reinhold.

Kays, S. J. (1999). Preharvest factors affecting appearance. Postharvest Biology and Technology, 15, 233e247.

Ke, D., Mateos, M., Siriphanich, J., Li, C., \& Kader, A. A. (1993) Carbon dioxide action on metabolism of organic and amino acids in crisphead lettuce. Postharvest Biology and Technology, 3, $235 \mathrm{e} 247$

Ke, D., \& Saltveit, M. E. (1989). Wound-induced ethylene production, phenolic metabolism and susceptibility to russet spotting in Iceberg lettuce. Physiologia Plantarum, 76, 412e418.

Kim, C., Hung, Y. C., \& Brackett, R. E. (2000). Roles of oxidatione reduction potential in electrolyzed oxidizing and chemically modified water for the inactivation of food-related pathogens. Journal of Food Protection, 63, 19e24.

Kim, J. G., Yousef, A. E., \& Chism, G. W. (1999). Applications of ozone for enhancing the microbiological safety and quality of foods: a review. Journal of Food Protection, 62(9), 1071e1087.

Klaiber, R. G., Baur, S., Wolf, G., Hammes, W. P., \& Carle, R. (2005) Quality of minimally processed carrots as affected by warm water washing and chlorination. Innovative Food Science and Emerging Technologies, 6, 351e362.
Klein, B. P. (1987). Nutritional consequences of minimal processing on fruits and vegetables. Journal of Food Quality, 10, 179e193.

Koseki, S., Yoshida, K., Isobe, S., \& Itoh, K. (2001). Decontamination of lettuce using acidic electrolyzed water. Journal of Food Protection, $64,652 \mathrm{e} 658$

Lamikanra, O. (2002). Preface. In O. Lamikanra (Ed.), Fresh-cut fruits and vegetables. Science, technology and market. Boca Raton, FL: CRC Press.

Lana, M. M., \& Tijskens, L. M. M. (2006). Effects of cutting and maturity on antioxidant activity of fresh-cut tomatoes. Food Chemistry, 97, 203e211.

Laties, G. G. (1978). The development and control of respiratory pathways in slices of plant storage tissues. In G. Kahl (Ed.), Biochemistry of wounded plant tissues (pp. 421e466). Berlin: Walter deGruyter.

Lee, S. Y., Costello, M., \& Kang, D. H. (2004). Efficacy of chlorine dioxide gas a sanitizer of lettuce leaves. Journal of Food Protection, $67,1371 \mathrm{e} 1376$

Leistner, L. (1999). Combined methods for food preservation. In M. Shafiur Rahman (Ed.), Food preservation handbook (pp. 457e485). New York: Marcel Dekker.

Lester, G. E., \& Grusak, M. A. (1999). Postharvest application of calcium and magnesium to honeydew and netted muskmelons: effects on tissue ion concentrations, quality, and senescence. Journal of the American Society of Horticultural Science, 124, 45e52.

Lewicki, P. P., Gondek, E., Wtrowa-Raichert, D., \& Nowak, D. (2001). Effect of drying on respiration of apple slices. Journal of Food Engineering, 49, 333e337.

Li, Y., Brackett, R. E., Chen, J., \& Beuchat, L. R. (2001). Survival and growth of Escherichia coli O157:H7 inoculated onto cut lettuce before or after heating in chlorinated water, followed by storage at 5 C or 15 C. Journal of Food Protection, 64(3), 305e309.

Li, Y., Brackett, R. E., Shewfelt, R. L., \& Beuchat, L. R. (2001). Changes in appearance and natural microflora on iceberg lettuce treated in warm, chlorinated water and then stored at refrigeration temperature. Food Microbiology, 18, 299e308.

Lindley, M. G. (1998). The impact of food processing on antioxidants in vegetable oils, fruits and vegetables. Trends in Food Science and Technology, 9, 336e340.

Liu, J., Stevens, C., Khan, V. A., Lu, J. Y., Wilson, C. L., Adeyeye, O., et al. (1993). Application of ultraviolet-C light on storage rots and ripening of tomatoes. Journal of Food Protection, 56(10), 868e872.

Loaiza-Velarde, J. G., Mangrich, M. E., Campos-Vargas, R., \& Saltveit, M. E. (2003). Heat shock reduces browning of fresh-cut celery petioles. Postharvest Biology and Technology, 27, 305e311.

Loaiza-Velarde, J. G., \& Saltveit, M. E. (2001). Heat shocks applied either before or after wounding reduce browning of lettuce leaf tissue. Journal of the American Society of Horticultural Science, $126,227 \mathrm{e} 234$.

Loaiza-Velarde, J. G., Tomas-Barberan, F. A., \& Saltveit, M. E. (1997) Effect of intensity and duration of heat-shock treatments on woundinduced phenolic metabolism in Iceberg lettuce. Journal of the American Society of Horticultural Science, 122, 873e877.

Lopez-Galvez, G., Saltveit, M. E., \& Cantwell, M. I. (1996). The visual quality of minimally processed lettuce stored in air or controlled atmospheres with emphasis on romaine and iceberg types. Postharvest Biology and Technology, 8, 179e190.

Luna-Guzman, I., \& Barrett, D. M. (2000). Comparison of calcium chloride and calcium lactate effectiveness in maintaining shelf stability and quality of fresh-cut cantaloupe. Postharvest Biology and Technology, 19, 61e72.

Luna-Guzman, I., Cantwell, M., \& Barrett, D. M. (1999). Fresh-cut cantaloupe: effects of $\mathrm{CaCl}_{2}$ dips and heat treatments on firmness and metabolic activity. Postharvest Biology and Technology, 17 201e213.

Main, G. L., Morris, J. R., \& Wehunt, E. J. (1986). Effect of preprocessing treatment on the firmness and quality characteristics of 
whole and sliced strawberries after freezing and thermal processing. Journal of Food Science, 51, 391e394.

Manganaris, G. A., Vasilakakis, M., Diamantidis, G., \& Mignani, I. (2007). The effect of postharvest calcium application on tissue calcium concentration, quality attributes incidence of flesh browning and cell wall physicochemical aspects of peach fruits. Food Chemistry, 4, 1385e1392.

Martın-Diana, A. B., Rico, D., Barry-Ryan, C., Frıas, J. M., Henehan,' G. T. M., \& Barat, J. M. Efficacy of steamer jet-injection as alternative to chlorine in fresh-cut lettuce. Postharvest Biology Technology, in press. doi:10.1016/j.postharvbio.2007.01.013.

Martin-Diana, A. B., Rico, D., Barry-Ryan, C., Frias, J. M., Mulcahy, J., \& Henehan, G. T. M. (2005a). Comparison of calcium lactate with chlorine as a washing treatment for fresh-cut lettuce and carrots: quality and nutritional parameters. Journal of the Science of Food and Agriculture, 85, 2260e2268.

Martin-Diana, A. B., Rico, D., Barry-Ryan, C., Frias, J. M., Mulcahy, J. \& Henehan, G. T. M. (2005b). Effect of calcium lactate concentration and temperature washing treatments on quality retention of salad-cut Iceberg lettuce. Food Research International, 38, 729e740.

Martin-Diana, A. B., Rico, D., Frias, J. M., Barry-Ryan, C., Mulcahy, J. \& Henehan, G. T. M. (2005). Effect of heat-shock on browningrelated enzymes in minimally processed Iceberg lettuce and crude extracts. Bioscience, Biotechnology and Biochemistry, 69(8), 1677 e1685.

Martın-Diana, A. B., Rico, D., Mulcahy, J., Frıas, J., Henehan, G. T. M.,' \& Barry-Ryan, C. (2006). Whey permeate as bio-preservative for shelf-life maintenance of fresh-cut vegetables. Innovative Food Science \& Technologies, 7, 112e123.

Menrad, K. (2003). Market and marketing of functional food in Europe. Journal of Food Engineering, 56, 181e188.

Meyer, A. S., Suhr, K. I., \& Nielsen, P. (2002). Natural food preservatives. In T. Ohlsson, \& N. Bengtsson (Eds.), Minimal processing technologies in the food industries. Cambridge, England: Woodhead Publishing Ltd.

Moreno, J., Chiralt, A., Escriche, I., \& Serra, J. A. (2000). Effect of blanching/osmotic dehydration combined methods on quality and stability of minimally processed strawberries. Food Research International, 33, 609e616.

Morris, J. R., Sistrunk, W. A., Sims, C. A., Main, G. L., \& Wehunt, E. J. (1985). Effects of cultivar, postharvest storage, pre-processing dip treatments and style of pack on the processing quality of strawberries. Journal of the American Society of Horticultural Science, $110,172 \mathrm{e} 177$.

Murata, M., Noda, I., \& Homma, S. (1995). Enzymatic browning of apples on the market: relationship between browning, polyphenol content and polyphenol oxidase. Nippon Shokuhin Kagaku Kogaku Kaishi, 42, 820e826.

Murata, M., Tanaka, E., Minoura, E., \& Homma, S. (2004). Quality of cut lettuce treated by heat shock: prevention of enzymatic browning, repression of phenylalanine ammonia-lyase activity, and improvement on sensory evaluation during storage. Bioscience, Biotechnology and Biochemistry, 68(3), 501e507.

Negi, P. S., \& Roy, S. K. (2000). Effect of blanching and drying methods on beta-carotene, ascorbic acid and chlorophyll retention of leafy vegetables. Food Science and Technology, 33, 295e298.

Nguyen-the, C., \& Carlin, F. (1994). The microbiology of minimally processed fresh fruits and vegetables. Critical Reviews in Food Science and Nutrition, 34(4), 371e401.

Ni, L., Lin, D., \& Barrett, D. M. (2005). Pectin methylesterase catalyzed firming effects on low temperature blanched vegetables. Journal of Food Engineering, 70, 546e556.

Nicoli, M. C., Elizalbe, B. E., Piotti, A., \& Lerici, C. R. (1991). Effects of sugars and Maillard reaction products on polyphenol oxidase activity in food. Journal of Food Biochemistry, 15, 169e184.

Niemira, B. A., Sommers, C. H., \& Fan, X. (2002). Suspending lettuce type influences recoverability and radiation sensitivity of
Escherichia coli O157:H7. Journal of Food Protection, 65, 1388e 1393.

Nigro, F., Ippolito, A., \& Lima, G. (1998). Use of UV-C light to reduce Botrytis storage rot of table grapes. Postharvest Biology and Technology, 13, 171e181.

Nykanen, A., Lapvetelainen, A., Hietnen, R. M., \& Kallio, H. (1998). The effect of lactic acid, nisin whey permeate sodium chloride and related combinations on aerobic plate count and the sensory characteristics of rainbow trout. LWT Food Science and Technology, 31, 286e290.

O'Beirne, D., \& Francis, G. A. (2003). Reducing the pathogen risk in MAP-prepared produce. In R. Ahvenainen (Ed.), Novel food packaging techniques (pp. 231e286). Cambridge, UK; Boca Raton, FL: Woodhead Publishing Limited/CRC Press LLC.

Ohlsson, T. (1980). Temperature dependence of sensory quality changes during thermal processing. Journal of Food Science, 45(4), 836e839.

Ohlsson, T. (1994). Minimal processing e preservation methods of the future: an overview. Trends in Food Science and Technology, 5(11), 341e344.

Ohlsson, T. (2002). Introduction. In T. Ohlsson, \& N. Bengtsson (Eds.), Minimal processing technologies in the food industry. Cambridge, UK: Woodhead publishing.

Ongeng, D., Devlieghere, F., Debevere, J., Coosemans, J., \& Ryckeboer, J. (2006). The efficacy of electrolysed oxidising water for inactivating spoilage microorganisms in process water and on minimally processed vegetables. International Journal of Food Microbilogy, 109(3), 289e291.

Orsat, V., Gariepy, Y., Raghavan, G. S. V., \& Lyew, D. (2001). Radiofrequency treatment for ready-to-eat fresh carrots. Food Research International, 34, 527e536.

Palou, E., Lopez-Malo, A., Barbosa-Canovas, G. V., \& Welti-Chanes, J. (2000). High hydrostatic pressure and minimal processing. In S. M. Alzamora, M. S. Tapia, \& A. Lopez-Malo (Eds.), Minimally processed fruits and vegetables (pp. 205e222). Maryland: Aspen.

Parish, M. E., Beuchat, L. R., Suslow, T. V., Harris, L. J., Garret, E. H., Farber, J. N., \& Busta, F. F. (2003). Methods to reduce/eliminate pathogens from fresh and fresh-cut produce. Comprehensive Reviews in Food Science and Food Safety, 2, 161e173.

Park, C. M., \& Beuchat, L. R. (1999). Evaluation of sanitizers for killing Escherichia coli O157:H7, Salmonella and naturally occurring microorganisms on cantaloupes, honeydew melons, and asparagus. Dairy, Food and Environmental Sanitation, 19, 842e847.

Piga, A., Agabbio, M., Gambella, F., \& Nicoli, M. C. (2002). Retention of antioxidant activity in minimally processed mandarin and satsuma fruits. LWT Food Science and Technology, 35, 344e347.

Polanska, M. (2001). Development of a new method for disinfection of drinking water. M.Sc. dissertation. Katholieke Hogeschool Sint-Lieven, Gent, Belgium and Wroclaw University of Technology, Wroclaw, Poland, pp. 1 e156.

Ponce, A. G., Roura, S. I., Del Valle, C. E., \& Fritz, R. (2002). Characterization of native microbial population of Swiss Chaed (Beta vulgaris, type cicla). Lebensmittel-Wissenschaft und-Technologie, 37, $199 \mathrm{e} 204$.

Poovaiah, B. W. (1986). Role of calcium in prolonging storage life of fruits and vegetables. Food Technology, 40(5), 86e89.

Priepke, P. E., Wei, L. S., \& Nelso, A. I. (1976). Refrigerated storage of prepackaged salad vegetables. Journal of Food Science, 41, 379e382.

Rame, J., Chaloupecky, V., Sojkova, N., \& Bencko, V. (1997). An attempt to demonstrate the increased resistance of selected bacterial strains during repeated exposure to UV radiation at $254 \mathrm{~nm}$. Central European Journal of Public Health, 4, 30e31.

Rico, D., Martin-Diana, A. B., Henehan, G. T. M., Frias, J. M., \& Barry-Ryan, C. (2006). Effect of ozone and calcium lactate treatments on browning and textured properties of fresh-cut lettuce. Journal of Food Science and Agriculture, 86, 2179e2188.

Rico, D., Martin-Diana, A. B., Henehan, J., Frias, J. M., Barat, G. T. M. \& Barry-Ryan, C. (2006). Improvement in texture using calcium 
lactate and heat-shock treatments for stored ready-to-eat carrots. Journal of Food Engineering, 79, 1196e1206

Roller, S. (2003). Natural antimicrobials for the minimal processing of foods. In S. Roller (Ed.). Cambridge, UK: Woodhead Publishing.

Chapt. 14. Combining

MAP with other preservation techniques. In R. Ahvenainen (Ed.), Novel food packaging techniques. Cambridge, England: Woodhead publishing Itd, ISBN 1855736756

Roy, S., Taylor, T., \& Kramer, H. (2001). Textural and ultrastructural changes in carrot tissue as affected by blanching and freezing Journal of Food Science, 66, 176e808.

Saftner, R. A., Baj, J., Abbott, J. A., \& Lee, Y. S. (2003). Sanitary dips with calcium propionate, calcium chloride, or calcium amino acid chelates maintain quality and shelf stability of fresh-cut honeydew chunks. Postharvest Biology and Technology, 29, 257e269.

Saltveit, M. E. (1993). A summary of CA and MA requirements and recommendations for the storage of harvested vegetables. Proceedings of the 6th National CA Conference (pp. 800e818). Cornell University, Ithaca, NY.

Saltveit, M. E. (2000). Wound-induced changes in phenolic metabolism and tissue browning are altered by heat shock. Postharvest Biology and Technology, 21, 61e69.

Saltveit, M. E. (2003). Is it possible to find an optimal controlled atmosphere? Postharvest Biology and Technology, 27, 3e13.

Saltveit, M. E., \& Loaiza-Velarde, J. G. (2000). Method of preventing wound-induced browning in produce. Patent $6,113,958$

Sapers, G. M. (2003). Washing and sanitizing raw materials for minimally processed fruit and vegetable products. In J. S. Novak, G. M. Sapers, \& V. K. Juneja (Eds.), Microbial safety of minimally processed foods (pp. 221e253). Boca Raton, New York: CRCPress

Seymour, I. J. (1999). Review of current industry practice on fruit and vegetable decontamination. [Review no. 14]. Gloucestershire, UK Campden \& Chorleywood Food Research Association. pp. 1 e38.

Shapiro, J. E., \& Holder, I. A. (1960). Effect of antibiotic and chemical dips on the microflora of packaged salad mix. Applied Microbiology, 8, 341

Shewfelt, R. (1994). Quality characteristics of fruits and vegetables. In R. P. Singh, \& F. A. R. Oliveira (Eds.), Minimal processing of foods and process optimization: an interface (pp. 171e189). Boca Raton, FL: CRC Press.

Singh, N., Singh, R. K., Bhunia, A. K., \& Stroshine, R. L. (2002) Efficacy of chlorine dioxide, ozone, and thyme essential oil or a sequential washing in killing Escherichia coli 0157:h7 on lettuce and baby carrots. LWT Food Science and Technology, 35, 720e729.

Sivertsvik, M., Rosnes, J. T., \& Bergslien, H. (2002). Modified atmosphere packaging. In T. Ohlsson, \& N. Bengtsson (Eds.), Minimal processing technologies in the food industry. Cambridge, UK Woodhead publishing

Skog, L. J., \& Chu, C. L. (2001). Effect of ozone on qualities of fruits and vegetables in cold storage. Canadian Journal of Plant Science, 81(4), $773 \mathrm{e} 778$

Smilanick, J. L., Crisosto, C., \& Mlikota, F. (1999). Postharvest use of ozone on fresh fruit. Perishables Handling Quarterly Issue, $99,10 \mathrm{e} 14$

Smout, C., Sila, D. N., Vu, T. S., Van Loey, A. M. L., \& Hendrickx, M. E. G. (2005). Effect of preheating and calcium pretreatment on pectin structure and thermal texture degradation: a case study on carrots. Journal of Food Engineering, 67, 419e425.

Song, J. Y., An, G. H., \& Kim, C. J. (2003). Color, texture, nutrient contents, and sensory values of vegetable soybeans [Glycine max (L.) Merrill] as affected by blanching. Food Chemistry, 83(1), 69e74

Stratilova, E., Markovic, O., Dzurova, M., Malovikova, A., Capek, P., \& Omelkova, J. (1998). The pectolytic enzymes of carrots. Biologia Bratislava, 53, 731e738.

Suutarinen, J., Anakainen, L., \& Autio, K. (1999). Comparison of light microscopy and spatially resolved Fourier transform infrared (FT-IR) microscopy in the examination of cell wall components of strawberries. LWT Food Science and Technology, 31, 595e601.

Szczesniak, A. S. (1998). The meaning of textural characteristics of crispiness. Journal of Textural Studies, 19, 51e59.

cott, S. T., \& Howard, L. R. (1999). Chemical and sensory quality of processed carrot puree as influenced by stress-induced phenolic compounds. Journal of Agricultural and Food Chemistry, 47 $1362 \mathrm{e} 1366$.

Tijskens, L. M. M. (2000). Acceptability. In L. R. Shewfelt, \& B. Bruckner (Eds.), Fruit and vegetable quality: an integrated view (pp. 125e 143). New York: CRC Press.

Toivonen, P. M. A., \& De-Ell, J. R. (2002). Physiology of fresh-cut fruits and vegetables. In O. Lamikanra (Ed.), Fresh-cut fruits and vegetables. Science, technology and market. Boca Raton, FL: CRC Press.

Toole, G. A., Parker, M. L., Smith, A. C., \& Waldron, K. W. (2000) Mechanical properties of lettuce. Journal of Material Science, 35 , 3553 e3559.

Tyagi, R. D., \& Kluepfel, D. (1998). Bioconversion of cheese whey to organics acids. In A. M. Martin (Ed.), Bioconversion of waste materials to industrial products. Glasgow' Blackie Academic

Uyttendaele, M., Neyts, K., Vanderswalmen, H., Notebaert, E., \& Debevere, J. (2004). Control of Aeromonas on minimally processed vegetables by decontamination with lactic acid, chlorinated water or thyme essential oil solution. International Journal of Food Microbiology, 90, 263e271.

Van Buren, J. P. (1979). The chemistry of texture in fruits and vegetables. Journal of Texture Studies, 10, 1e23.

Varoquaux, P., \& Wiley, R. (1994). Biological and biochemical changes in minimally processed refrigerated fruits and vegetables. In R. C. Wiley (Ed.), Minimally processed refrigerated fruits and vegetables (pp. 226e268). New York, USA: Chapman and Hall.

Vickers, A. M. (1988). Instrumental measures of crispiness and their correlation with sensory assessment. Journal of Textural Studies, 19, 1 e14.

Vu, T. S., Smout, C., Sila, D. N., LyNguyen, B., Van Loey, A. M. L., \& Hendrickx, M. E. G. (2004). Effect of preheating on thermal degradation kinetics of carrot texture. Innovative Food Science and Emerging Technologies, 5, 37e44.

Walker, J. R. L. (1977). Enzymatic browning in foods. Its chemistry and control. Food Technology New Zealand, 12, 19e25.

Wang, H., Feng, H., \& Luo, Y. (2004). Microbial reduction and storage quality of fresh-cut cilantro washed with acidic electrolyzed water and aqueous ozone. Food Research International, 37 949e956.

Watada, A. E., \& Qui, L. (1999). Quality of fresh-cut produce. Postharvest Biology and Technology, 15, 201e205

Wei, C. I., Huang, T. S., Kim, J. M., Lin, W. F., Tamplin, M. L., \& Bartz, J. A. (1999). Growth and survival of Salmonella montevideo on tomatoes and disinfection with chlorinated water. Journal of Food Protection, 58, 829e836.

White, G. C. (1992). Ozone. In: Handbook of chlorination and alternative disinfectants (3rd ed.). (pp. 1046e1110) New York: Van Nostrand Reinhold.

Willkox, F., Mercier, M. Hendrickx, M. \& Tobback, P. (1993). Modelling the influence of temperature and carbondioxide upon the growth of Pseudomonas fluorescens. Food Microbiology, 10, $159 \mathrm{e} 173$.

Zawistowski, J., Biliaderis, C. G., \& Eskin, N. A. M. (1995). In: D. S. Robinson, \& N. A. M. Eskin (Eds.), Oxidative enzymes in foods (pp. 217). New York: Elsevier.

Zhang, L., Zhaoxin, L., Zhifang, Y., \& Xiang, G. (2005). Preservation of fresh-cut celery by treatment of ozonated water. Food Control, 16 $279 \mathrm{e} 283$.

Zhang, S., \& Farber, J. M. (1996). The effects of various disinfectants against Listeria monocytogenes on fresh-cut vegetables. Food Microbiology, 13, 311e321. 